\title{
Synthesis, Spectroscopic and Thermal Characterization of Copper(II) and Iron(III) Complexes of Folic Acid and Their Absorption Efficiency in the Blood
}

\author{
E. Hamed, ${ }^{1}$ M. S. Attia, ${ }^{1}$ and K. Bassiouny ${ }^{2}$ \\ ${ }^{1}$ Department of Chemistry, Faculty of Science, Ain Shams University, Cairo, Egypt \\ ${ }^{2}$ Department of Biochemistry, Genetic Engineering and Biotechnology Research Institute (GEBRI), Menoufia University, \\ Sadat City, Egypt
}

Correspondence should be addressed to E. Hamed, dr_science_7@hotmail.com

Received 10 March 2009; Revised 27 April 2009; Accepted 5 June 2009

Recommended by Igor Fritsky

The absorption efficiency of any drug in blood is of prime importance. Compounds having the general formula: $\mathrm{K}_{\mathrm{n}}\left[\mathrm{M}(\mathrm{FO})_{2}\left(\mathrm{H}_{2} \mathrm{O}\right)_{2}\right] \cdot x \mathrm{H}_{2} \mathrm{O}$, where $(\mathrm{M}=\mathrm{Cu}(\mathrm{II})$ or $\mathrm{Fe}(\mathrm{III}), \mathrm{n}=2$ or 1 , $\mathrm{FO}=$ folate anion, $x=2$ or 3 with respect $)$, were prepared, and their absorption efficiency in rodent's blood was determined. The obtained compounds were characterized by elemental analysis, infrared as well as thermogravimetric analysis and polarization of light. The results suggest that the two folate complexes were formed in 1:2 molar ratio (metal : folic acid) which acted as a bidentate ligand through both carboxylic groups. Polarization of light proved that the folate complexes have symmetric geometry. Biological application proved that $\mathrm{Cu}$ (II) and $\mathrm{Fe}$ (III) complexes were absorbed more efficiently in rodent blood than folic acid itself.

Copyright ( 2009 E. Hamed et al. This is an open access article distributed under the Creative Commons Attribution License, which permits unrestricted use, distribution, and reproduction in any medium, provided the original work is properly cited.

\section{Introduction}

Folic acid as reported in the figure, $\mathrm{N}-(4\{[(2$-amino4-oxo-1, 4-dihydropteridin-6-yl)methyl] amino benzoyl)-Lglutamic acid is from a group of vitamins called water soluble vitamins which contain B-Group vitamins and the other group. It is fat-insoluble vitamins, acting as a coenzyme in many single carbon transfer reactions in the synthesis of DNA, RNA, and protein components [1]. It is called pteroylL-glutamic acid (PGA), see Figure 1. The occurrence of folic acid in nature is not in appreciable amounts, though it is assimilated in the body and is converted to the active cofactor form of the vitamin [2]. Folic acid deficiency results in DNA strand breaks [3], DNA hypomethylation [4], and abnormal gene expression [5].

It has been shown that folic acid supplementation can significantly reduce the risk of these disorders [6-14]. Folates are the key cofactors in one-carbon metabolism. Together with other substrates and cofactors it is involved in the synthesis of the purine ring, conversion of 2-deoxyuridine monophosphate to thymidine monophosphate, via $S$ adenosylmethionine. Over 80 methylation reactions are known to date $[15,16]$. Given the importance of onecarbon metabolism in a broad variety of metabolic pathways, it is not entirely surprising that abnormal, notably low, folate status is associated with risk for seemingly unrelated developmental anomalies and diseases, ranging from neural tube defects, Alzheimer dementia, pregnancy complications, inflammatory disease, osteoporosis and cancer to coronary artery disease. Severe micronutrient deficiencies usually cause readily recognizable symptoms, such as anemia in folate deficiency, but the effects of subclinical deficiencies on disease development are not readily apparent, since they usually operate over prolonged periods of time [17]. The structural diversity encountered in metal-folate complexes could be attributed to the versatile ligational behavior of the carboxylate group which can function like a bidentate ligand binding to a single metal or alternatively as a bridging bidentate ligand coordinating to two metals or as a monodentate ligand $[18,19]$. The three different coordination modes were reported in literature $[20,21]$. The aim of the present work is to demonstrate the enhancement of the absorption efficiency of folic acid in blood by using biological saving metals as $\mathrm{Fe}$ and $\mathrm{Cu}$ which already exist in human blood and also to show 
<smiles>Nc1nc2ncc(CNc3ccc(C(=O)N[C@@H](CCC(=O)O)C(=O)O)cc3)nc2c(=O)[nH]1</smiles>

FIGURE 1: Structure of folic acid.

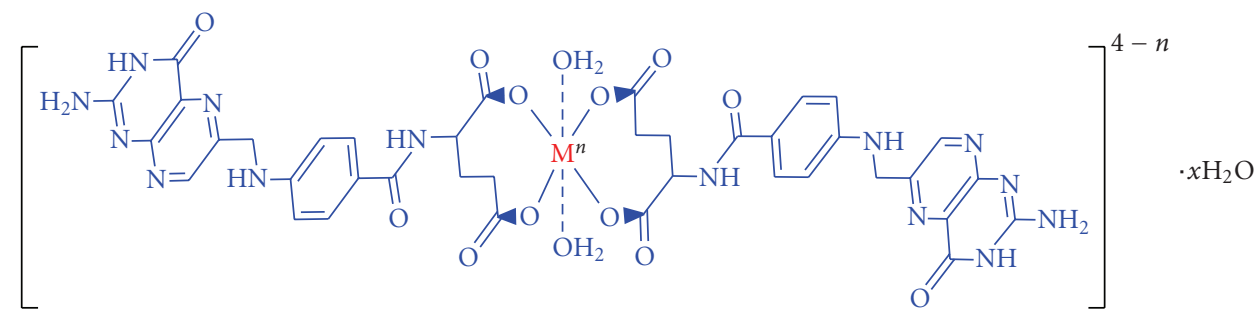

FIgURE 2: The expected structure of the two complexes.

the way in which these transition metals combine with folic acid. The composition and structure of the complexes were identified using: elemental analysis $(\mathrm{C}, \mathrm{H}, \mathrm{N}), \mathrm{FTIR}$, atomic absorption, light polarization, and TGA techniques.

\section{Experimental: Materials and Instrumentation}

2.1. Materials. All chemicals used in the present study are reagent grade,

(1) Folic acid, Adwic $\left(\mathrm{C}_{19} \mathrm{H}_{19} \mathrm{~N}_{7} \mathrm{O}_{6} \cdot 2 \mathrm{H}_{2} \mathrm{O}\right)$ (Figure 1) used without further purification.

(2) The following metal basic carbonates were used in preparing the solid folate complexes after determining their metal content after dissolution in the least amount of dilute nitric acid, by atomic absorption spectrometry

(i) $\mathrm{CuCO}_{3} \cdot \mathrm{Cu}(\mathrm{OH})_{2} \cdot \mathrm{H}_{2} \mathrm{O}$

(ii) $\mathrm{Fe}_{2}\left(\mathrm{CO}_{3}\right)_{3} \cdot 3 \mathrm{Fe}(\mathrm{OH})_{3} \cdot 5 \mathrm{H}_{2} \mathrm{O}$.

\subsection{Instrumentation}

Elemental Analysis. C, H, and N were determined at the microanalytical laboratory, Cairo and Ain Shams Universities using a Perkin Elmer $2400 \mathrm{CHN}$ elemental analyzer. Copper and iron were determined by atomic absorption spectrometry (AAS), using Perkin Elmer AAS 3100. A given weight of the complex was heated with concentrated nitric acid nearly to dryness. The resulting metal nitrate was dissolved in distilled water and the solution made to volume in a measuring flask. Standard metal solution series is prepared by diluting calculated volumes of a standard stock solution of the metal to the mark in a volumetric flask. The hollow cathode lamp of our metals concerned are used, the current adjusted to the recommended value and the metal line. $(\lambda \mathrm{nm})$ is selected to give the maximum absorption using the appropriate monochromator slit width. The absorbance of the sample is read and the concentration of the metal is determined from the calibration curve constructed from the absorbances of the standard solutions.

Atomic Absorption Measurements. Thermogravimetric analysis was carried out using a Perkin-Elmer 7 Series thermal analyzer. The measurements were carried out under nitrogen atmosphere at a heating rate $10{ }^{\circ} \mathrm{C} / \mathrm{min}$.

Optical Measurements. Polarimetric measurement was recorded on a Courtesy Messrs, Hilgher and Watts, Ltd., London polarimeter. The field of view appears dark (which occurs when the axes of the two prisms are at right angles to each other).

I.R. Spectra. I.R. spectra of the solid complexes were recorded on a Perkin-Elmer spectrometer Model Jasco FTIR300E Fourier Transform Infrared Spectrometer, using $\mathrm{KBr}$ discs in the range $400-4000 \mathrm{~cm}^{-1}$.

Solubility. The solubility of the prepared complexes was determined by shaking few milligrams of the complex with about $25 \mathrm{~mL}$ of aliquots of distilled water in a water thermostat at $25{ }^{\circ} \mathrm{C} \pm 0.2$ for about 3 hours. The suspension was rapidly filtered and measured aliquots of the filtrate titrated against standard $\mathrm{HCl}$ solution using methyl orange as indicator (Table 1).

Synthesis of Metal Complexes. Cu-folates, $\mathrm{K}_{2}\left[\mathrm{Cu}(\mathrm{FO})_{2}\right.$ $\left.\left(\mathrm{H}_{2} \mathrm{O}\right)_{2}\right] \cdot 2 \mathrm{H}_{2} \mathrm{O}$ (the complex color is yellowish green). The complex was prepared by mixing $(0.1 \mathrm{~mol})$ of the metal carbonate with $0.2 \mathrm{~mol}$ of folic acid in $\sim 50 \mathrm{~mL}$ of distilled 
TABLE 1: Elemental analysis and solubility of the complexes.

\begin{tabular}{|c|c|c|c|c|c|c|c|c|c|}
\hline \multirow[t]{2}{*}{ Metal complexes } & \multirow[t]{2}{*}{ Solubility (g/L) } & \multicolumn{2}{|c|}{ Metal } & \multicolumn{2}{|r|}{$\mathrm{C}$} & \multicolumn{2}{|r|}{$\mathrm{H}$} & \multicolumn{2}{|r|}{$\mathrm{N}$} \\
\hline & & $\mathrm{Cal} \%$ & Found \% & $\mathrm{Cal} \%$ & Found \% & $\mathrm{Cal} \%$ & Found \% & $\mathrm{Cal} \%$ & Found \% \\
\hline $\mathrm{K}_{2}\left[\mathrm{Cu}(\mathrm{FO})_{2}\left(\mathrm{H}_{2} \mathrm{O}\right)_{2}\right] 2 \mathrm{H}_{2} \mathrm{O}$ (yellowish green) & $2.18 \mathrm{~g} / \mathrm{L}$ & 5.83 & 6.09 & 41.85 & 41.08 & 3.67 & 3.27 & 17.99 & 16.30 \\
\hline $\mathrm{K}\left[\mathrm{Fe}(\mathrm{FO})_{2}\left(\mathrm{H}_{2} \mathrm{O}\right)_{2}\right] 3 \mathrm{H}_{2} \mathrm{O}($ dark brown $)$ & $1.67 \mathrm{~g} / \mathrm{L}$ & 5.47 & 4.87 & 42.98 & 42.29 & 3.83 & 3.36 & 18.47 & 17.91 \\
\hline
\end{tabular}

water. (The $\mathrm{pH}$ of the folic acid solution is adjusted to about $7.6-7.8$ by adding $0.2 \mathrm{M}$ of $\mathrm{KHCO}_{3}$ solution and warmed at about $\sim 60^{\circ} \mathrm{C}$ before adding the metal carbonate). After complete reaction, the solution was concentrated to about $25 \mathrm{~mL}$, it was then cooled in ice-cold water where crystals of copper folate complex separated out on addition of little ethyl alcohol, filtered and recrystallized from warming water, washed with ethyl alcohol and kept in a vacuum desiccators over dried silica gel. Fe-Folates, $\mathrm{K}\left[\mathrm{Fe}(\mathrm{FO})_{2}\left(\mathrm{H}_{2} \mathrm{O}\right)_{2}\right] \cdot 3 \mathrm{H}_{2} \mathrm{O}$ (the complex color is dark brown). A similar procedure as that described for copper folate complex was carried out, for the preparation of the $1: 2$ iron complex.

Ethical Considerations. All animal experimental procedures had full approval from the Animal Ethics Committee of Menoufia University.

Animals. White albino mice were obtained from the experimental animal house of the Genetic Engineering \& Biotechnology Institute, Menoufia University.

All mice had free access to commercial pelleted food and tap water. The mice were maintained at an ambient temperature of $22^{\circ} \mathrm{C}$ with 12 hours light/dark cycles.

Drug Administration Procedure. A group of male mice was given orally $100 \mathrm{mg} / \mathrm{kg}$ body weight of folic acid or its complexes (copper-folate and iron-folate), all preparations are dissolved and suspended in distilled water, five individuals were used for each treatment of folic acid and its complexes. Two hours after treatment mice were killed and plasma collected for investigations.

\section{Results and Discussion}

Results of elemental analysis and some physical characteristics of the obtained complexes are shown in Table 1. The complexes are air stable, and they have high-melting point. Their solubility in water is $\sim\left(10^{-1} \mathrm{~mol}\right)$ in $\mathrm{H}_{2} \mathrm{O}$. Elemental analysis data of the complexes indicate that the complexes have the $1: 2$ stoichiometry (metal : ligand) with general formulae shown in (Table 1).

3.1. Optical Measurements. The polarimeter consists of a monochromatic light source, a polarizer, a sample cell, a second polarizer, which is called the analyzer, and a light detector. The analyzer is oriented $90^{\circ}$ to the polarizer so that no light reaches the detector. When an optically active substance is present in the beam, it rotates the polarization of the light reaching the analyzer so that there is a component that reaches the detector. The angle that the analyzer must be rotated to return to the minimum detector " $\alpha$ " signal is the optical rotation angle.

Polarimetric measurements on solutions of the two complexes showed that both complexes possess no angle of rotation $(\alpha=0)$, that is, having plane of symmetry. It is thus concluded that they have an octahedral structure with two trans coordinate water molecules, as shown in Figure 2.

3.2. Infrared Spectra. The essential infrared data are summarized in Table 2. Folic acid exhibits a very strong absorption band at $1718 \mathrm{~cm}^{-1}$ due to the stretching vibration of $\nu(\mathrm{C}=\mathrm{O})$ of free ketonic of the carboxylic group [21]. This group is shifted or disappeared in the spectra of its complexes accompanied by the appearance of two bands in the 1569$1631 \mathrm{~cm}^{-1}$ range due to $v_{\text {as }}(\mathrm{COO}-)$ and one in the 1350 $1413 \mathrm{~cm}^{-1}$ range assigned to $v_{\mathrm{s}}(\mathrm{COO}-)$. Accordingly, the antisymmetric and symmetric stretching vibration modes $\left(\nu_{\text {as }}(\mathrm{COO}-)\right.$ and $\left.\nu_{s}(\mathrm{COO}-)\right)$ of the $\mathrm{COO}-$ group should help in elucidating the structure of our complexes [22].

The direction of the frequency shift of the $v_{\text {as }}(\mathrm{COO}-)$ and the $v_{\mathrm{s}}(\mathrm{COO}-)$ bands with respect to those of the free ion depends on the coordination mode of the $\mathrm{COO}$ - group with the metal ion. Nakamoto and McCarthy [21, 23] claimed that if the coordination is monodentate the $v_{\mathrm{as}}(\mathrm{COO}-)$ and $v_{s}(\mathrm{COO}-)$ will be shifted to higher and lower frequencies, respectively. Whereas, if the coordination is chelating bidentate or bridging bidentate both $\nu_{\text {as }}\left(\mathrm{COO}^{-}\right)$and $\nu_{\mathrm{s}}\left(\mathrm{COO}^{-}\right)$ frequencies will change in the same direction. This is because the bond orders of both $\mathrm{C}=\mathrm{O}$ bonds would change by the same amount. Based on these facts and comparing the $v_{\text {as }}\left(\mathrm{COO}^{-}\right)$and $v_{\mathrm{s}}\left(\mathrm{COO}^{-}\right)$frequencies of the folate complexes by the $v_{\mathrm{as}}\left(\mathrm{COO}^{-}\right)$and $v_{\mathrm{s}}\left(\mathrm{COO}^{-}\right)$frequencies of potassium carboxylate [24], as shown in Table 3 and Figure 2 one can say that all the prepared complexes are metal chelats in contradistinction to what is described in [21], because both $v_{\text {as }}\left(\mathrm{COO}^{-}\right)$and $v_{\mathrm{s}}\left(\mathrm{COO}^{-}\right)$frequencies will change in the opposite direction this indicates that the carboxylic group is monodentate coordinate. The broad stretching vibration of $\mathrm{OH}^{-}$group $v(\mathrm{O}-\mathrm{H})$ occurred as expected [25] at $3397 \mathrm{~cm}^{-1}$. The amide fragments are shown in (Table 2) by i.r. about $3200 \mathrm{~cm}^{-1}(\nu \mathrm{NH})$, in $1652-1658 \mathrm{~cm}^{-1}$ region $(\nu(\mathrm{C}=\mathrm{O})$ amide $\mathrm{I})$, and about $1520 \mathrm{~cm}^{-1}(\delta(\mathrm{NH})$ amide $\mathrm{II})$ [26-28].

3.3. Thermogravimetric Analysis. Thermal analysis curves (TG/DTG) of folic acid and its transition metal complexes are studied and interpreted as follows. The folic acid ligand melts at $220^{\circ} \mathrm{C}$ with simultaneous decomposition $[20,21]$. From the TG curve for copper folate complex (Figure 4), it appears that the sample decomposes in four endothermic 
TABLE 2: IR frequencies $\left(\mathrm{Cm}^{1}\right)$ of folic acid (FO) and its metal complexes.

\begin{tabular}{|c|c|c|c|}
\hline \multirow{2}{*}{ Assignments } & \multicolumn{3}{|c|}{ Compounds } \\
\hline & Folic acid & $\begin{array}{l}\text { Fe-folate } \\
\text { complex }\end{array}$ & $\begin{array}{l}\text { Cu-folate } \\
\text { complex }\end{array}$ \\
\hline$v(\mathrm{OH}) ; \mathrm{H}_{2} \mathrm{O}$ & $\begin{array}{l}3421 \\
3415\end{array}$ & 3381 & 3388 \\
\hline$v(\mathrm{NH})$ amide & 3230 & 3175 & 3220 \\
\hline$v_{\mathrm{as}}(\mathrm{CH})$ & $\begin{array}{l}3106 \\
2926\end{array}$ & $\begin{array}{l}3090 \\
2930\end{array}$ & $\begin{array}{l}3030 \\
2930\end{array}$ \\
\hline$v_{\mathrm{s}}(\mathrm{CH})$ & 2840 & $\begin{array}{l}2820 \\
2770\end{array}$ & $\begin{array}{l}2830 \\
2805\end{array}$ \\
\hline$v(\mathrm{C}=\mathrm{O})$ amide $\mathrm{I}$ & 1652 & 1658 & 1655 \\
\hline$\nu(\mathrm{COOH})$ & 1718 & - & - \\
\hline$v_{\mathrm{as}}(\mathrm{COO}-)$ & 1569 & 1613 & 1603 \\
\hline$\delta(\mathrm{CH})$ & $\begin{array}{l}1483 \\
1413\end{array}$ & $\begin{array}{l}1448 \\
1401\end{array}$ & $\begin{array}{l}1445 \\
1400\end{array}$ \\
\hline$v_{\mathrm{s}}(\mathrm{COO}-)$ & 1453 & 1369 & 1350 \\
\hline$\delta(\mathrm{NH})$ amide II & 1528 & 1520 & 1532 \\
\hline$\nu_{\mathrm{as}}(\mathrm{CC})$ & 1323 & 1303 & 1300 \\
\hline$v(\mathrm{CN})$ & $\begin{array}{l}1230 \\
1191 \\
1106\end{array}$ & $\begin{array}{l}1185 \\
1106\end{array}$ & $\begin{array}{l}1186 \\
1102\end{array}$ \\
\hline$v_{\mathrm{s}}(\mathrm{CC})$ & 971 & 980 & 955 \\
\hline$\delta(\mathrm{CC})$ & 764 & 767 & 766 \\
\hline$v(\mathrm{M}-\mathrm{O})$ & - & $\begin{array}{l}587 \\
520\end{array}$ & $\begin{array}{l}585 \\
521\end{array}$ \\
\hline
\end{tabular}

TABle 3: Asymmetric and Symmetric Stretching Vibrations of the Carboxylate group.

\begin{tabular}{|c|c|c|c|c|}
\hline Compound & $v_{\mathrm{as}}(\mathrm{COO})$ & $v_{\mathrm{s}}(\mathrm{COO})$ & $v \Delta=v_{\mathrm{as}}\left(\mathrm{COO}^{-}\right)-v_{\mathrm{s}}\left(\mathrm{COO}^{-}\right)$ & Bonding mode \\
\hline Folic acid & 1569 & 1453 & 116 & - \\
\hline $\mathrm{K}\left[\mathrm{Fe}(\mathrm{FO})_{2}\left(\left(\mathrm{H}_{2} \mathrm{O}\right)_{2}\right] \cdot 2 \mathrm{H}_{2} \mathrm{O}\right.$ & 1631 & 1369 & 262 & Mono dentate \\
\hline $\mathrm{K}_{2}\left[\mathrm{Cu}(\mathrm{FO})_{2}\left(\mathrm{H}_{2} \mathrm{O}\right)_{2}\right] \cdot 2 \mathrm{H}_{2} \mathrm{O}$ & 1603 & 1350 & 253 & Mono dentate \\
\hline
\end{tabular}

TABLe 4: The concentration of $\mathrm{Cu}$ and Fe elements in mice blood serum in case of folic acid and folic acid metal complex.

\begin{tabular}{lllll}
\hline Elements & $\begin{array}{l}\mathrm{Cu}(\mathrm{mg} / \mathrm{L}) \\
\text { (After inject of } \\
\text { folic acid) }\end{array}$ & $\begin{array}{l}\mathrm{Cu}(\mathrm{mg} / \mathrm{L})(\mathrm{after} \\
\text { inject complex })\end{array}$ & $\begin{array}{l}\text { Fe }(\mathrm{mg} / \mathrm{L})(\mathrm{after} \\
\text { inject of folic } \\
\text { acid) }\end{array}$ & $\begin{array}{l}\mathrm{Fe}(\mathrm{mg} / \mathrm{L})(\mathrm{after} \\
\text { inject complex })\end{array}$ \\
\hline Mice 1 & 5.1 & 6.4 & 7.9 & 12.4 \\
Mice 2 & 4.8 & 6.9 & 8.3 & 13.2 \\
Mice 3 & 4.9 & 7.6 & 7.7 & 11.8 \\
Mice 4 & 5.1 & 7.2 & 9.2 & 14.7 \\
Mice 5 & 5.1 & 6.9 & 10.2 & 16.9 \\
\hline
\end{tabular}

TABle 5: Comparison between the normal, folic acid case and folic acid metal complex case percentage of $\mathrm{Cu}$ and $\mathrm{Fe}$ elements in the serum of mice.

\begin{tabular}{lccc}
\hline Metal ion & Normal concentration in the blood mg/L & After inject of folic acid mg/L & After inject complex mg /L \\
\hline $\mathrm{Cu}(\mathrm{mg} / \mathrm{L})$ & 1.18 & $5.00 \pm 0.21$ & $7 \pm 0.6$ \\
$\mathrm{Fe}(\mathrm{mg} / \mathrm{L})$ & 2.1 & $9.2 \pm 0.15$ & $13.8 \pm 0.8$ \\
\hline
\end{tabular}




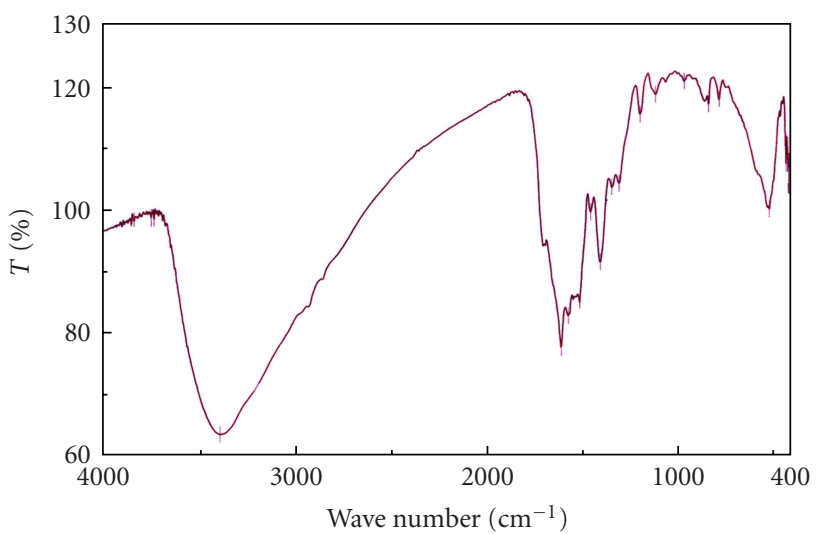

FIGURE 3: I.R. Spectrum of iron folate complex.

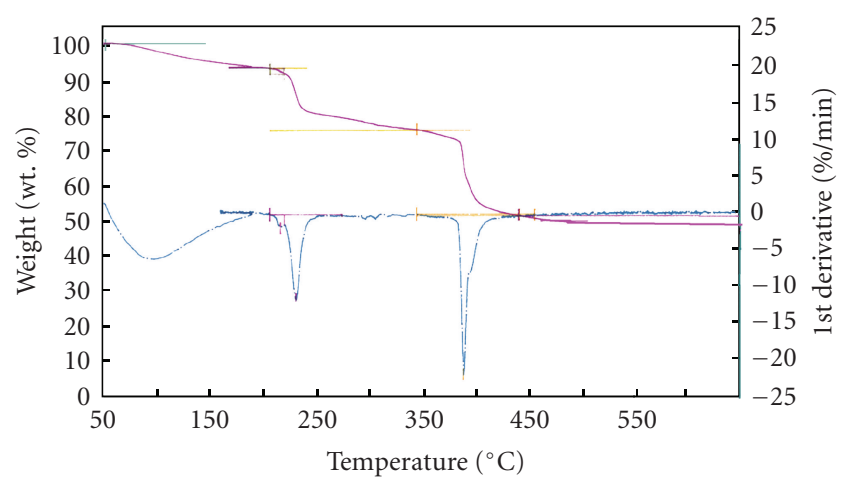

FIgURE 4: TG and DTG of copper complex.

peaks over the temperature range $\left(0-600^{\circ} \mathrm{C}\right)$. The first step occurs from $50-170{ }^{\circ} \mathrm{C}$ corresponding to the loss of four $\mathrm{H}_{2} \mathrm{O}$ molecules representing weight loss (obs. $=6.66 \%$ and calc. $=6.61 \%)$. The second and third steps from $170{ }^{\circ} \mathrm{C}-$ $599{ }^{\circ} \mathrm{C}$ corresponding to the loss of $\mathrm{C}_{7} \mathrm{H}_{32} \mathrm{~N}_{14} \mathrm{O}_{11}$ (organic part) molecules, representing weight loss (obs. $=44.13 \%$ and calc. $=44.79 \%$ ). The last one over $600{ }^{\circ} \mathrm{C}$ was accompanied by mass loss (obs. $=49.21 \%$ and calc. $=48.60 \%$ ) as metallic and carbon residue are the final product.

The thermal decomposition of iron folate complex, occurs completely in four steps. The first step in the range $50.7{ }^{\circ} \mathrm{C}-192.4{ }^{\circ} \mathrm{C}$ corresponding to the loss of 5 $\mathrm{H}_{2} \mathrm{O}$ molecules representing weight loss (obs. $=8.92 \%$ and calc. $=8.48 \%)$. The second and third steps from $218^{\circ} \mathrm{C}-$ $596{ }^{\circ} \mathrm{C}$ corresponding to the loss of $\mathrm{C}_{7} \mathrm{H}_{31} \mathrm{~N}_{14} \mathrm{O}_{11}$ (organic part) molecules representing weight loss (obs. $=46.3 \%$ and calc. $=45.9 \%)$. The last one over $600{ }^{\circ} \mathrm{C}$ was accompanied by mass loss (obs. $=44.74 \%$ and calc. $=44.77 \%$ ) as metallic and carbon residue is the final product.

3.4. Biological Applications. Atomic absorption data (Tables 4 and 5) proved that the values for the concentration of metal ion in blood in the presence of the folic acid are higher than those in absence of the folic acid. This means that folic acid withdraws the metal ion from the body forming the complex in blood. It may be concluded that the folic acid in the complexed form absorbed more efficienty in the rodent blood than the folic acid itself.

Inspection of the results shown in Table 4 reveals that the copper and iron contents in mice blood increases significantly on feeding the rodents with folic acid copper and iron complexes. The absorption of folic acid complexes is much better than folic acid absorption itself shown in Table 5. So, these complexes can be used as analogues for folic acid alone.

This may be explained as being due to the high solubility differences between folic acid which is considered as an insoluble material, and its copper and iron complexes are shown in Table 1.

\section{Conclusion}

The complexation between transition metal ions as (Fe(III) and $\mathrm{Cu}$ (II)) with folic acid resulted in the formation $(1: 2)$ molar ratio (metal : folic acid). Folic acid acts as a bidentate ligand via two monodentate carboxylate groups giving the general formula: $\left[\mathrm{M}(\mathrm{FO})_{2}\left(\mathrm{H}_{2} \mathrm{O}\right)_{n}\right] \cdot x \mathrm{H}_{2} \mathrm{O}$, where $\mathrm{FO}=$ folate anion; $n=2$ and $x=2$ or 3 . The resulted folate compounds were assigned by infrared, optical measurements. Thermogravimetric analysis and atomic absorption of folate complexes. The transition metals folic acid complexes are more preferred than folic acid itself as a drug in the human body because the abs orption efficiencies of the transition metal complexes are higher than those the folic acid.

\section{References}

[1] S. Ruggeri, L. T. Vahteristo, A. Aguzzi, P. Finglas, and E. Carnovale, "Determination of folate vitamers in food and in Italian reference diet by high-performance liquid chromatography," Journal of Chromatography A, vol. 855, no. 1, pp. 237245, 1999.

[2] R. Devi, J. Arcot, S. Sotheeswaran, and S. Ali, "Folate contents of some selected Fijian foods using tri-enzyme extraction method," Food Chemistry, vol. 106, no. 3, pp. 1100-1104, 2008.

[3] I. P. Pogribny, A. G. Basnakian, B. J. Miller, N. G. Lopatina, L. A. Poirier, and S. J. James, "Breaks in genomic DNA and within the p53 gene are associated with hypomethylation in livers of folate/methyl-deficient rats," Cancer Research, vol. 55, no. 9, pp. 1894-1901, 1995.

[4] I. P. Pogribny, B. J. Miller, and S. J. James, "Alterations in hepatic p53 gene methylation patterns during tumor progression with folate/methyl deficiency in the rat," Cancer Letters, vol. 115, no. 1, pp. 31-38, 1997.

[5] E. Wainfan and L. A. Poirier, "Methyl groups in carcinogenesis: effects on DNA methylation and gene expression," Cancer Research, vol. 52, pp. 2071s-2077s, 1992.

[6] M. I. Botez, S. N. Young, and J. Bachevalier, "Effect of folic acid and vitamin B12 deficiencies on 5-hydroxyindoleacetic acid in human cerebrospinal fluid," Annals of Neurology, vol. 12, no. 5, pp. 479-484, 1982.

[7] L. E. Daly, P. N. Kirke, A. Molloy, D. G. Weir, and J. M. Scott, "Folate levels and neural tube defects: implications for prevention," Journal of the American Medical Association, vol. 274, no. 21, pp. 1698-1702, 1995.

[8] Y.-I. Kim, "Folate and carcinogenesis: evidence, mechanisms, 
and implications," Journal of Nutritional Biochemistry, vol. 10, no. 2, pp. 66-88, 1999.

[9] M. P. Mattson, I. I. Kruman, and W. Duan, "Folic acid and homocysteine in age-related disease," Ageing Research Reviews, vol. 1, no. 1, pp. 95-111, 2002.

[10] M. C. Verhaar, E. Stroes, and T. J. Rabelink, "Folates and cardiovascular disease," Arteriosclerosis, Thrombosis, and Vascular Biology, vol. 22, no. 1, pp. 6-13, 2002.

[11] D. L. Smith and O. A. Bodamer, "Practical management of combined methylmalonicaciduria and homocystinuria," Journal of Child Neurology, vol. 17, no. 5, pp. 353-356, 2002.

[12] M. P. Mattson and T. B. Shea, "Folate and homocysteine metabolism in neural plasticity and neurodegenerative disorders," Trends in Neurosciences, vol. 26, no. 3, pp. 137-146, 2003.

[13] J. L. Moore, "The significance of folic acid for epilepsy patients," Epilepsy and Behavior, vol. 7, no. 2, pp. 172-181, 2005.

[14] C. Matté, E. Durigon, F. M. Stefanello, F. Cipriani, M. Wajner, and A. T. S. Wyse, "Folic acid pretreatment prevents the reduction of $\mathrm{Na}^{+}, \mathrm{K}^{+}$-ATPase and butyrylcholinesterase activities in rats subjected to acute hyperhomocysteinemia," International Journal of Developmental Neuroscience, vol. 24, no. 1, pp. 3-8, 2006.

[15] P. J. Stover, "Physiology of folate and vitamin B12 in health and disease," Nutrition Reviews, vol. 62, no. 6, pp. S3-S13, 2004.

[16] J. B. Mason, "Biomarkers of nutrient exposure and status in one-carbon (methyl) metabolism," Journal of Nutrition, vol. 133, supplement 3, pp. 941S-947S, 2003.

[17] F. A. J. Muskiet, "The importance of (early) folate status to primary and secondary coronary artery disease prevention," Reproductive Toxicology, vol. 20, no. 3, pp. 403-410, 2005.

[18] R. C. Mehrotra and R. Bohra, Metal Carboxylates, Academic Press, London, UK, 1983.

[19] R. C. Mehrotra and A. Singh, "Recent trends in metal alkoxide chemistry," Progress in Inorganic Chemistry, vol. 46, pp. 239454, 1997.

[20] G. B. Deacon and A. D. M. Phillips, "Relationships between the carbon-oxygen stretching frequencies of carboxylato complexes and the type of carboxylate coordination," Coordination Chemistry Reviews, vol. 33, no. 3, pp. 227-250, 1980.

[21] M. G. A. El-Wahed, M. S. Refat, and S. M. El-Megharbel, "Synthesis, spectroscopic and thermal characterization of some transition metal complexes of folic acid," Spectrochimica Acta A, vol. 70, no. 4, pp. 916-922, 2008.

[22] M. A. Mesubi, "An infrared study of zinc, cadmium, and lead salts of some fatty acids," Journal of Molecular Structure, vol. 81, no. 1-2, pp. 61-71, 1982.

[23] K. Nakamato and P. J. McCarthy, Spectroscopy and Structure of Metal Chelate Compounds, John Wiley \& Sons, New York, NY, USA, 1968.

[24] R. Goto and T. Takenaka, Journal of the Chemical Society of Japan, vol. 84, pp. 392-401, 1963.

[25] L. S. Gelfand, F. J. Iaconianni, L. L. Pytlewski, A. N. Speca, C. M. Mikulski, and N. M. Karayannis, "Nicotinic and isonicotinic acid n-oxide interactions with $3 \mathrm{~d}$ metal perchlorates," Journal of Inorganic and Nuclear Chemistry, vol. 42, no. 3, pp. 377-385, 1980.

[26] Ts. Kolev, B. B. Koleva, S. Y. Zareva, and M. Spiteller, “Au(III)complexes of the alanyl-containing peptides glycylalanine and glycylalanylalanine-synthesis, spectroscopic and structural characterization," Inorganica Chimica Acta, vol. 359, no. 13, pp. 4367-4376, 2006.

[27] B. B. Koleva, Ts. Kolev, S. Y. Zareva, and M. Spiteller, "The dipeptide alanylphenylalanine (H-Ala-Phe-OH)protonation and coordination ability with $\mathrm{Au}(\mathrm{III})$," Journal of Molecular Structure, vol. 831, no. 1-3, pp. 165-173, 2007.

[28] B. B. Ivanova, S. T. Todorov, and M. G. Arnaudov, "Lineardichroic infrared and NMR spectroscopic analysis of an $\mathrm{Au}(\mathrm{III})$ complex of glycylmethioninylglycine," Journal of Coordination Chemistry, vol. 59, no. 15, pp. 1749-1755, 2006. 


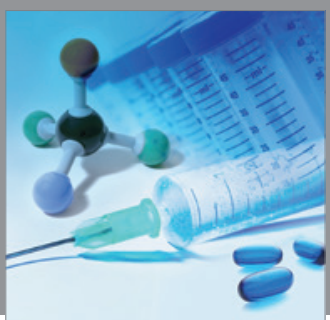

International Journal of

Medicinal Chemistry

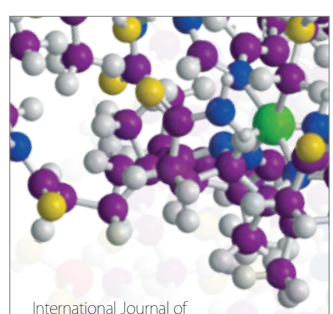

Carbohydrate Chemistry

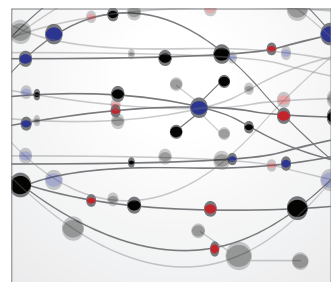

The Scientific World Journal
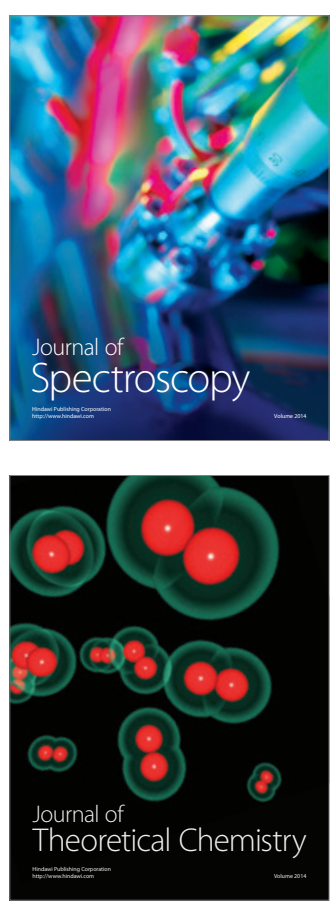
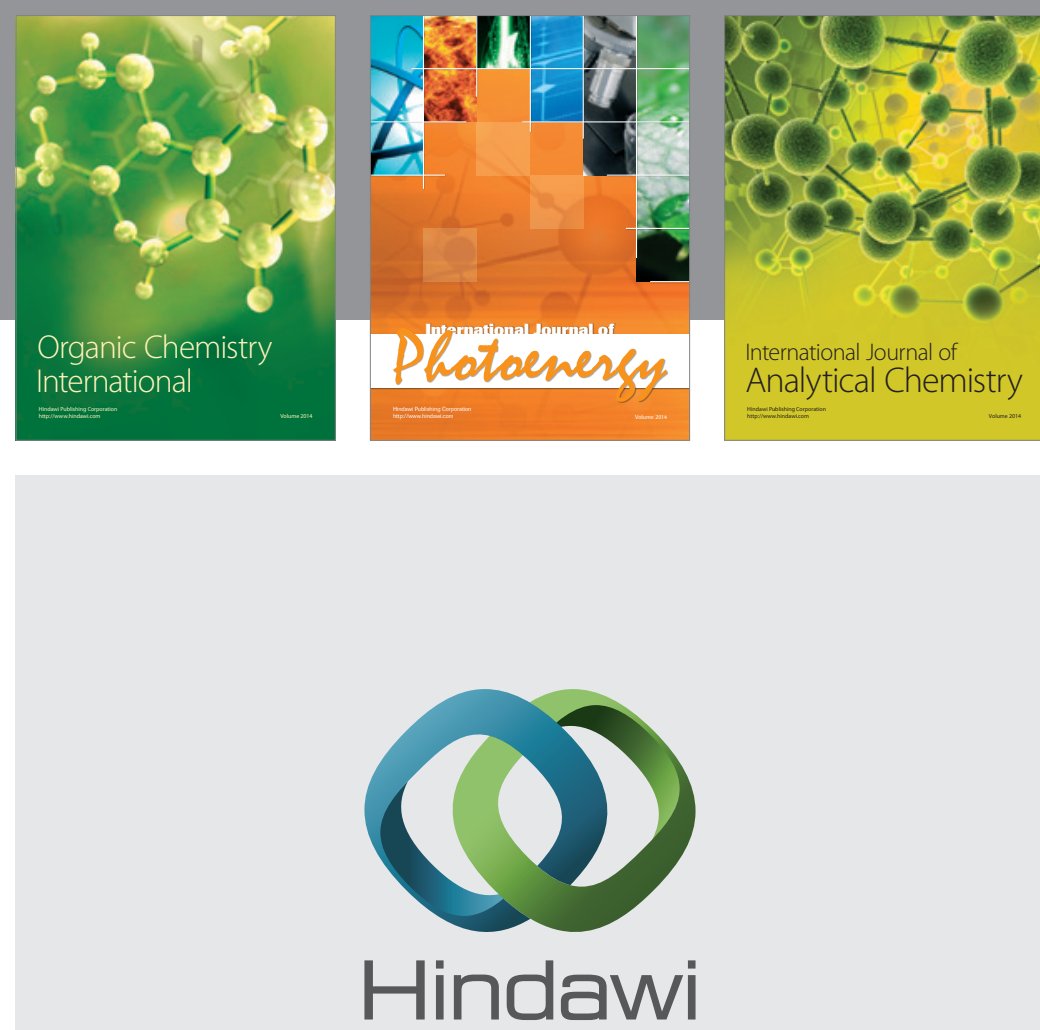

Submit your manuscripts at

http://www.hindawi.com
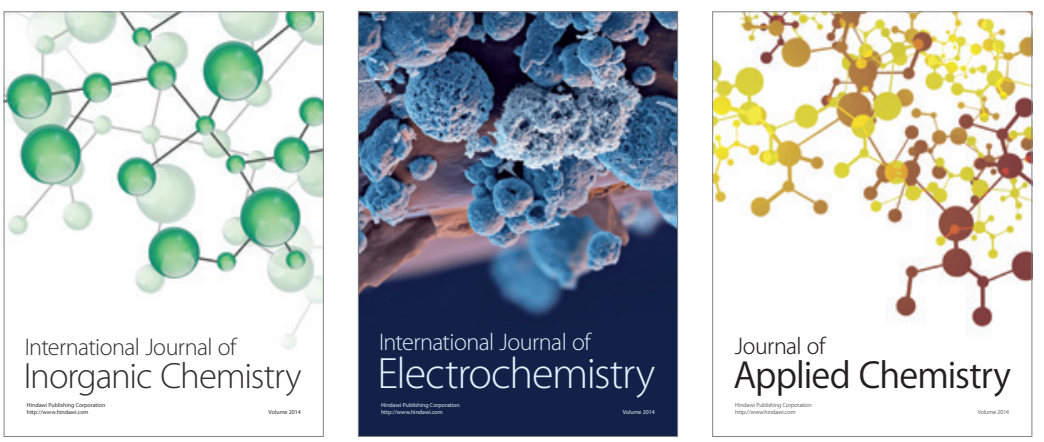

Journal of

Applied Chemistry
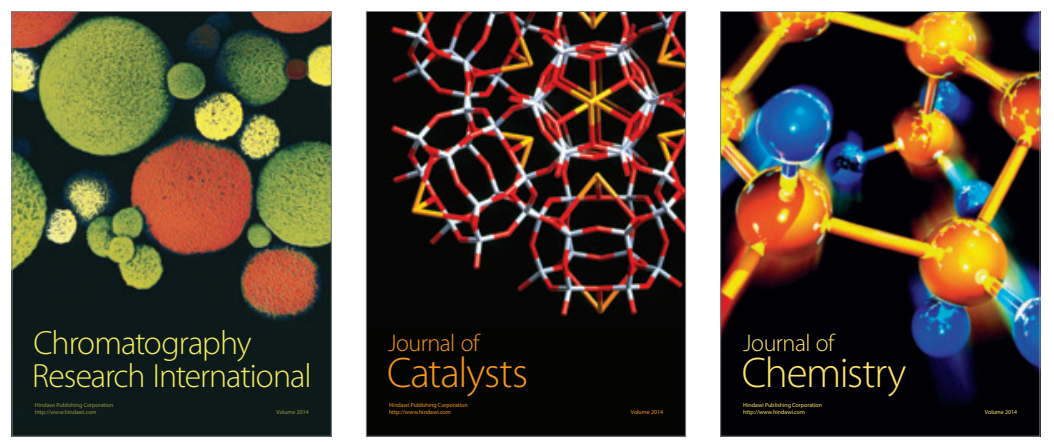
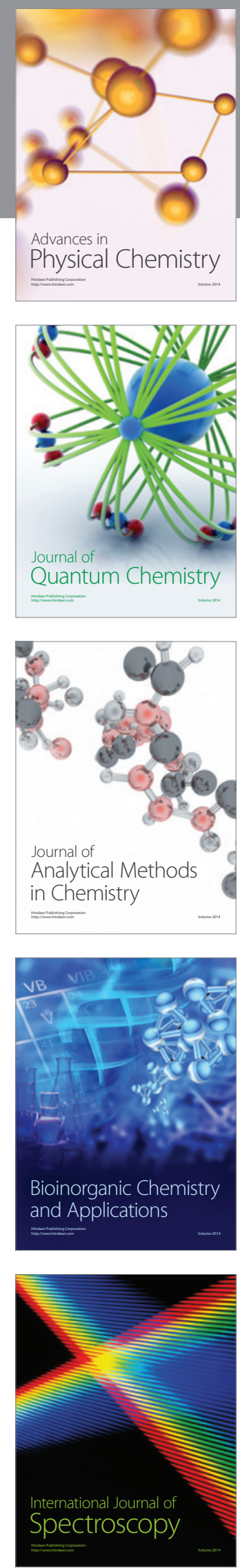